\title{
Land Use Change Detection in OMO Biosphere Reserve Using GIS and Remote Sensing
}

\author{
Uzoma Darlington Chima (Corresponding author) \\ Department of Forestry and Wildlife Management, \\ Faculty of Agriculture, University of Port Harcourt, Nigeria \\ Tel: 234-803-812-1887Ｅ-mail: uzoma.chima@uniport.edu.ng \\ Moses Oladepo Adedire \\ Department of Forestry and Wildlife Management, \\ College of Environmental Resources Management, \\ Federal University of Agriculture, Abeokuta, Nigeria \\ E-mail: moadedire@ hotmail.com
}

Received: December 16, 2013 Accepted: June 3, $2014 \quad$ Published: November 5, 2014

doi:10.5296/jee.v5i2.4774ＵRL: http://dx.doi.org/10.5296/jee.v5i2.4774

\begin{abstract}
Inadequacy of reliable data on the rate and extent of forest conversion remains a major problem threatening sustainable forest management in Nigeria. In this study, we examined land use change pattern in Omo Biosphere Reserve, Nigeria, between 1987 and 2011. Landsat TM imagery for 1987 and Landsat $\mathrm{ETM}^{+}$imagery for 2011 were analyzed for land use change detection using Erdas Imagine 9.2 and ArcGIS 9.2. The results showed that farmlands, disturbed forests, settlements and rivers increased in area while the areas covered by the natural forests, plantations, and roads decreased from the 1987 figures. The farmlands had the highest increase in area (19025 hectares) from 1987 figures, followed by disturbed forests (10917 hectares), settlements (4262 hectares), and rivers (235 hectares). The highest reduction in area was observed for plantations (22699 hectares), followed by natural forest (10803 hectares) and roads (937 hectares). As at 1987, the natural forest was the most extensive land cover type, occupying $39.32 \%$ of the reserve. However, the disturbed forest is now the most extensive of all the land use types covering $36.34 \%$ of the reserve, followed by the natural forest $(32.05 \%)$, farmland $(14.78 \%)$, plantation $(10.62 \%)$, settlement $(4.11 \%)$, roads $(1.22 \%)$, and rivers $(0.87 \%)$. There was a drift in the abundance of the natural forest
\end{abstract}


cover from the northeastern part of the reserve in 1987 to the northwestern part in 2011 due to unsustainable exploitation in the former and various conservation projects in the later. It is expected that the information provided in this study will aid decisions that will enhance sustainable management of the reserve.

Keywords: Remote sensing, GIS, Land use change detection, Omo Biosphere Reserve 


\section{Introduction}

The rate of deforestation and forest degradation in developing countries of the world is quite alarming in recent times. Around 13 million hectares of forest were converted to other uses, largely agriculture, or lost through natural causes each year in the last decade (FAO, 2010). Environmental stress by disruptive deforestation has continued to impact on the rainforest ecosystem in Nigeria. Howard (1991) observed that "in the scenario of a rapidly expanding world population, changes in land use and declining land cover, remote sensing has the role of an emerging discipline, and provides essential tool to the field forester. As an important tool, remotely sensed data from different earth observation satellites are available to monitor the spatial evolution of tropical forest ecosystems (Runge, 2006).

Current technologies such as geographical information systems (GIS) and remote sensing provide ample opportunities for understanding landscape dynamics. They are powerful tools to derive accurate and timely information on the spatial distribution of land use/land cover changes over large areas (Carlson and Azofeifa, 1999; Guerschman et al, 2003; Rogana and Chen, 2004; Zsuzsanna et al, 2005).

In Nigeria, there are evidences of successful application of remote sensing technologies in land use/ land cover change detection in the rainforest zone (e.g. Salami, 1999; Salami et al, 1999; Salami, 2006; Ikhuoria et al, 2006; Nuga and Akinbola, 2011). The Nigerian Conservation Foundation (NCF, 2008) has also employed these technologies to map out the remaining natural forest cover in Omo, Oluwa, Shasha, Ife and Ago-Owu forest reserves in Southwestern Nigeria. However, the study by NCF did not capture the rate and pattern of deforestation/natural forest conversion in these reserves over time. As a result, Ogunsesan et al. (2011) stressed the need for the production of new and accurate maps of the forest reserves to inform government, local people, and planners, and to ensure more effective management.

Considering the international status of Omo Biosphere Reserve and the palpable land use/land cover changes, it is imperative to take advantage of the GIS and remote sensing technologies to ascertain the extent and rate of natural forest conversion in the reserve. It is expected that such information will enhance management decisions that will ensure sustainable management of the reserve.

\section{Materials and Methods}

\subsection{Description of the Study Area}

\subsubsection{Location}

Omo Biosphere Reserve is located between latitudes $6^{\circ} 35^{\prime}$ to $7^{\circ} 05^{\prime} \mathrm{N}$ and longitudes $4^{\circ} 19^{\prime}$ to $4^{\circ} 40^{\prime} \mathrm{E}$ in the South-west of Nigeria (Ojo, 2004); about $135 \mathrm{~km}$ north-east of Lagos, about $120 \mathrm{~km}$ east of Abeokuta and about $80 \mathrm{~km}$ east of Ijebu Ode (Ola-Adams, 1999). The reserve shares a common boundary in its northern part with two other forest reserves - Ago Owu and Shasha in Osun State. It also has a common boundary with Oluwa Forest Reserve in Ondo State (Karimu, 1999); and covers 130,500 hectares of land (Ola, Adams, 1999; Ojo, 2004). 


\section{Macrothink}

Figure 1 is the map of Omo biosphere reserve showing the surrounding reserves.

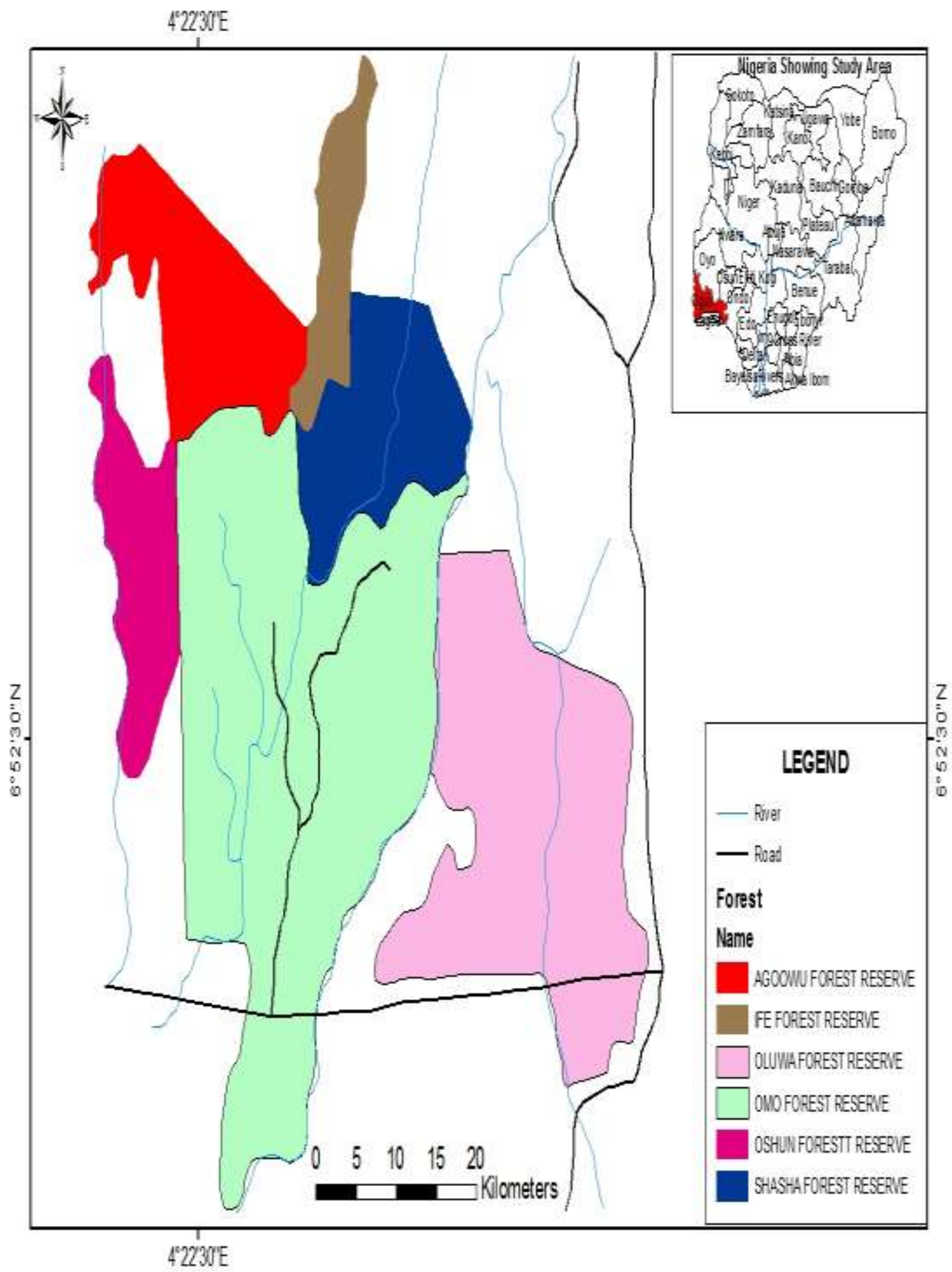

Figure 1. Map of Omo biosphere reserve showing the surrounding reserves (Inset: Map of Nigeria showing the study area)

Source: Adapted from Ola-Adams (1999) 


\subsubsection{Vegetation}

The reserve is in the mixed moist semi-evergreen rainforest zone. The northern parts of the reserve are relatively dry forest with typical species such as Sterculia rhinopetala while Nauclea diderrichii and Terminalia superba are common in the wetter central parts; in the wet forests on sandy swampy soils in the south, lophira and trees in the Meliaceae family are common (Ola-Adams, 1999). As a result of continuous human activities, mainly logging and farming for almost a century, the vegetation pattern in Omo has changed remarkably. The reserve now carries monocultures of Gmelina arborea, Tectona grandis, Theobroma cacao; and arable farmlands. Natural forests of varying degrees of disturbance and a 460-hectare Strict Nature Reserve (SNR) which was established in 1946 as an inviolate plot but later designated an SNR also exist. The SNR is located in Area J1 by Omo River, just a few kilometers south of the confluence of Omo and Owena rivers in the north central part of the reserve.

\subsubsection{Soils and Topography}

The soils are predominantly Ferruginous tropical (Hall, 1977). They are of the Ferric Luvisols type of the higher category of classification (Chijioke, 1980). The reserve is made up of several soil types but all belong to the tertiary sediments (Ola-Adams, 1999). Geologically, the reserve lies on crystalline rocks of the undifferentiated basement complex which in the southern parts is overlain by Eocene deposits of sand, clay and gravel (Isichei, 1995). The terrain is undulating and the maximum elevation of $150 \mathrm{~m}$ above sea level is towards the west while the lowest parts of the Reserve are in the south where the River Omo joins River Oni before flowing into the Lekki Peninsular on the Atlantic coast. The Lagos-Ore-Benin Highway passes through the southern part of the Reserve.

\subsubsection{Climate}

The climate of Omo Biosphere Reserve has been extensively described by Ola-Adams (1999). The Reserve falls within the tropical wet-and-dry climate characterized by two rainfall peaks separated by a relatively less humid period usually in the month of August. The mean annual rainfall is about $1750 \mathrm{~mm}$, while mean relative humidity is $80 \%$. The mean daily temperature is $26.4{ }^{\circ} \mathrm{C}$ and this has been found to be $0.6{ }^{\circ} \mathrm{C}$ higher than the mean daily temperature of 25.8 ${ }^{0} \mathrm{C}$ recorded by Evans (1939). Generally, sunshine duration during the rainy season varies between 8-10 hours.

\subsection{Method of Data Collection}

The imageries used for the land use analysis were those of Landsat TM for 1987 and Landsat $\mathrm{ETM}^{+}$for 2011, acquired directly from Tropical Rainforest Information Centre, Department of Forestry, Michigan State University, U.S.A., in March, 2012. The properties of the Landsat $\mathrm{TM}$ and Landsat $\mathrm{ETM}^{+}$imageries used for the study are shown in Table 1. 
Table 1. Properties of Landsat imageries used for the study

\begin{tabular}{lll}
\hline & Landsat TM & Landsat ETM $^{+}$ \\
\hline Scene ID & LT51900551987002AAA03 & LE71900552011012ASN00 \\
Path & 190 & 190 \\
Row & 55 & 55 \\
Acquisition date & $02-01-1987$ & $12-01-2011$ \\
Sensor & TM & ETM $^{+}$ \\
Spatial resolution & $30 \mathrm{~m}(120 \mathrm{~m}-$ thermal $)$ & $30 \mathrm{~m}(60 \mathrm{~m}-$ thermal, 15m - pan $)$ \\
Spectral range & $0.45-12.5 \mu \mathrm{m}$ & $0.45-12.5 \mu \mathrm{m}$ \\
Number of bands & 7 & 8 \\
Temporal resolution & 16 days & 16 days \\
Image size & $185 \mathrm{~km}$ x $172 \mathrm{~km}$ & $183 \mathrm{~km} \times 170 \mathrm{~km}$ \\
Swath & $185 \mathrm{~km}$ & $183 \mathrm{~km}$ \\
\hline
\end{tabular}

Both remote sensing and GIS technologies were used to generate land use maps for 1987 and 2011 and to calculate the area of each land use type in hectares for the respective years. The Landsat imageries for each year were imported to Erdas Imagine 9.2 where the imageries were enhanced by combining the bands through the COMPOSITE module.

Unsupervised classification was done based on spectral differences in the imageries using CLUSTER module. The classification made it possible to capture each land use type in polygons in vector format in ArcGIS 9.2. Subsequently, the name of each land use was given based on the ground-truthing exercise made during reconnaissance survey to the study area. Relational database was generated for each land use type. The database was then queried using QUERY BUILDER in order to calculate the area of each land use type.

\section{Results}

The land use maps of the reserve for 1987 and 2011 are shown in Figures 1 and 2 respectively while the summary of land use changes between 1987 and 2011 is presented in Table 2. The farmlands, disturbed forests, settlements and rivers increased in area while the areas covered by the natural forests, plantations, and roads decreased from the 1987 figures. The farmlands had the highest percentage increase in area, followed by settlements, disturbed forests, and rivers respectively, while the highest reduction in area was observed for plantations, followed by roads, and the natural forests respectively. As at 1987, the natural forest covered a larger area $(39.32 \%)$ of the reserve than each of the other land use types, while in 2011, the disturbed forest (covering 36.34\% of the reserve) was the land use occupying the largest area. 


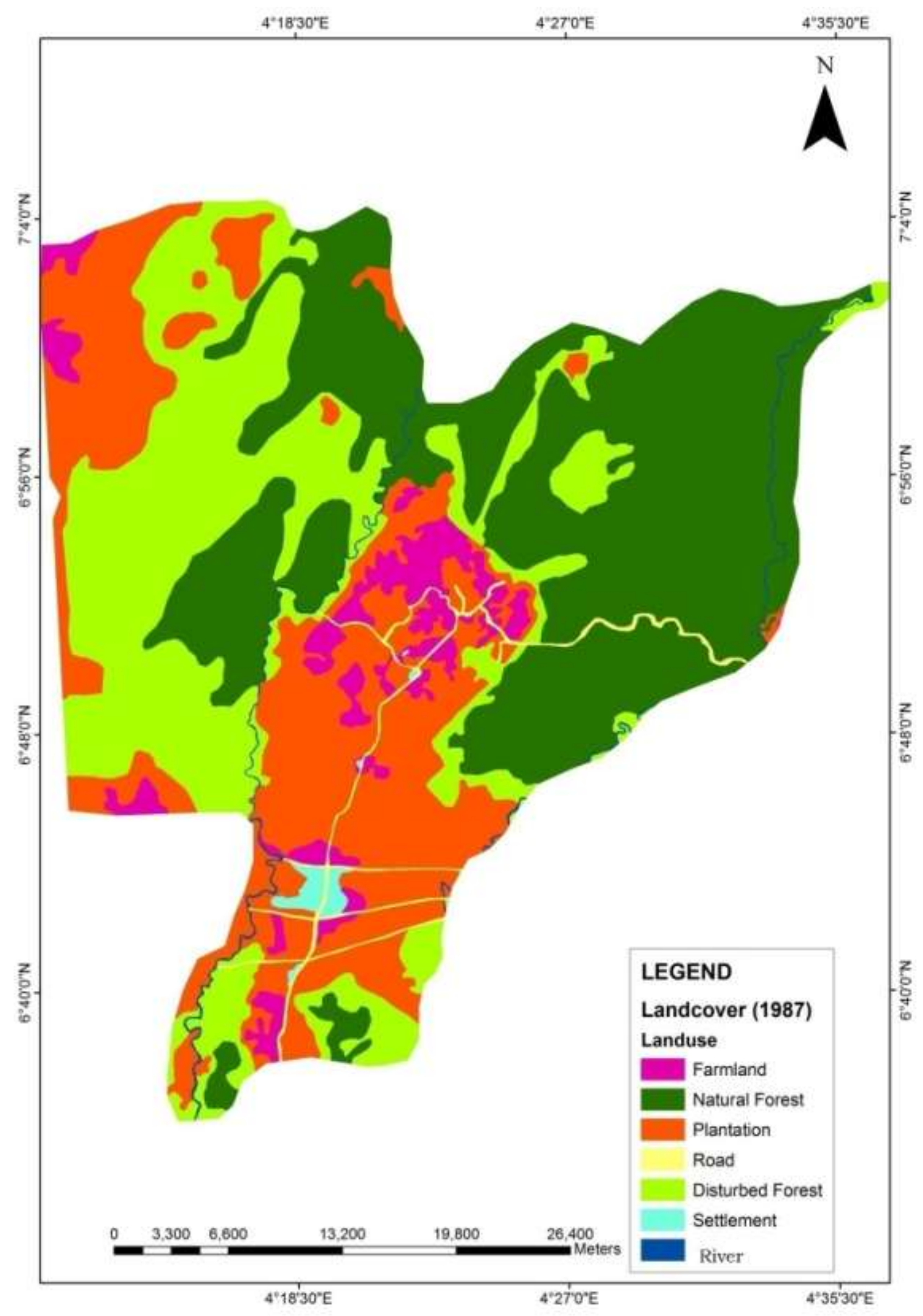

Figure 1. Land use map of Omo Biosphere Reserve for 1987 


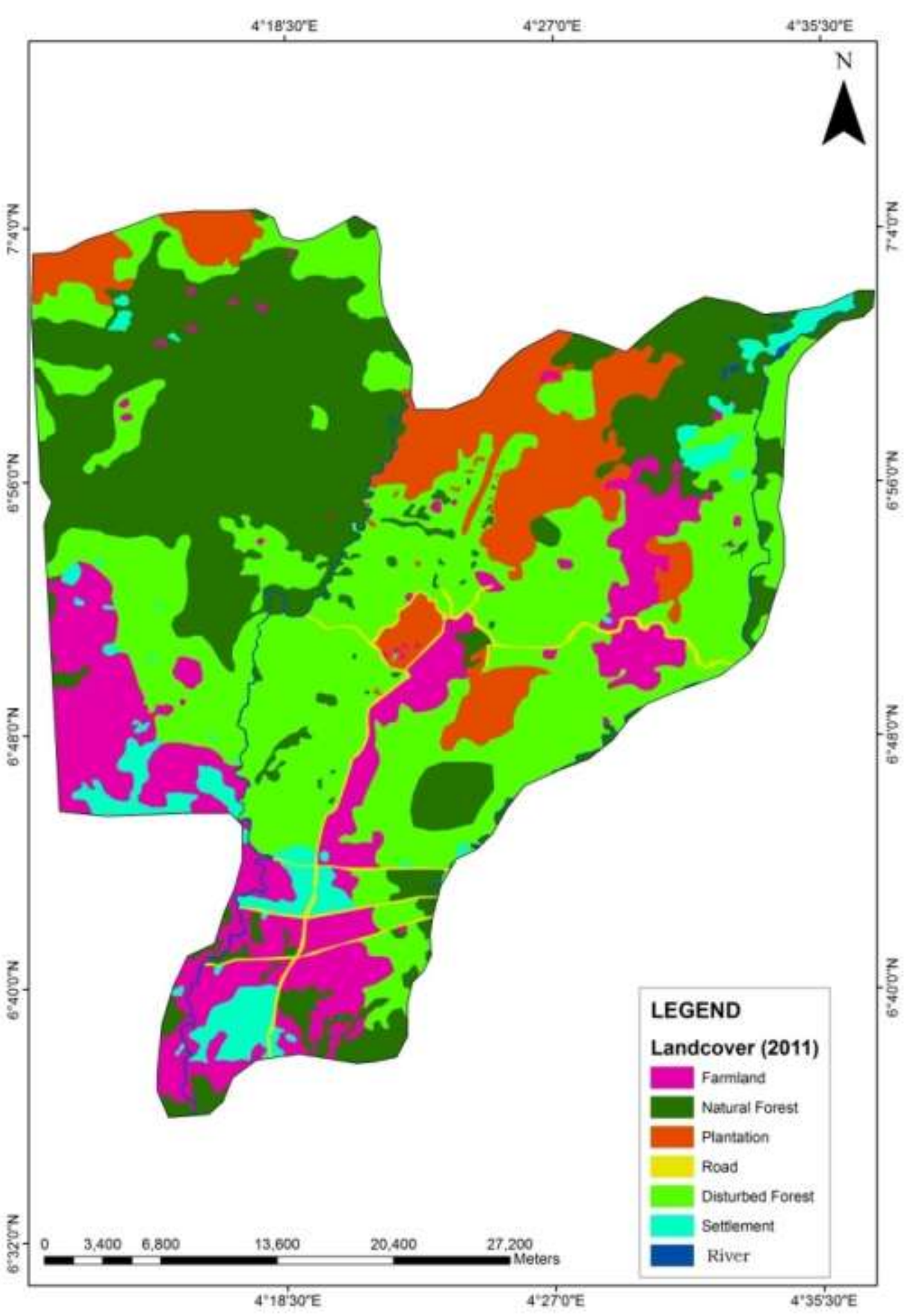

Figure 2. Land use map of Omo Biosphere Reserve for 2011 
Table 2. Summary of land use changes in hectares

\begin{tabular}{|c|c|c|c|c|}
\hline Land use & 1987 & 2011 & Change (hectares) & $\%$ Change \\
\hline Farmland & $\begin{array}{l}2956 \\
(1.99)\end{array}$ & $\begin{array}{l}21981 \\
(14.78)\end{array}$ & 19025 & $-643.61 *$ \\
\hline $\begin{array}{l}\text { Natural } \\
\text { Forest }\end{array}$ & $\begin{array}{l}58457 \\
(39.32)\end{array}$ & $\begin{array}{l}47654 \\
(32.05)\end{array}$ & 10803 & 18.48 \\
\hline Plantation & $\begin{array}{l}38487 \\
(25.88)\end{array}$ & $\begin{array}{l}15788 \\
(10.62)\end{array}$ & 22699 & 58.98 \\
\hline Road & $\begin{array}{l}2757 \\
(1.85)\end{array}$ & $\begin{array}{l}1820 \\
(1.22)\end{array}$ & 937 & 33.99 \\
\hline $\begin{array}{l}\text { Disturbed } \\
\text { Forest }\end{array}$ & $\begin{array}{l}43120 \\
(29.00)\end{array}$ & $\begin{array}{l}54037 \\
(36.34)\end{array}$ & 10917 & $-25.32 *$ \\
\hline Settlement & $\begin{array}{l}1855 \\
(1.25)\end{array}$ & $\begin{array}{l}6117 \\
(4.11)\end{array}$ & 4262 & $-229.9 *$ \\
\hline Water Body & $\begin{array}{l}1055 \\
(0.71)\end{array}$ & $\begin{array}{l}1290 \\
(0.87)\end{array}$ & 235 & $-22.27 *$ \\
\hline Total & 148687 & 148687 & & \\
\hline
\end{tabular}

( ) Numbers in brackets are percentages of total land area of the reserve covered by each land use type for the respective years.

* Negative value indicates corresponding increase in area of the respective land use types from the 1987 figures.

\section{Discussion}

The land use analysis revealed a remarkable change in land use within the reserve between 1987 and 2011. The farmlands, disturbed forests, settlements, and rivers increased in area while the areas covered with natural forests, plantations, and roads decreased.

The tremendous increase in farmlands could be attributed to increasing human populations and the need to produce more food to feed them, and also for income generation. Reports have shown that $40 \%$ of the land surface of the earth was converted into cropland and permanent pasture by early 1990s (Rajiv and Upandhyay, 1999). As human populations continue to grow, land use intensity increases, and the negative effects of deforestation are likely to worsen (Chazdon, 2003). Karimu (1999) equally noted that settlements in the reserve have continued to increase in number and size since after a survey conducted in the area between 1916 and 1918, which reported the existence of 5 villages, a total of 30 settlements and a human population of 610. Ola-Adams (1999) reported that people were permitted to remain living within the $65 \mathrm{~km}^{2}$ of enclaves as at the time the reserve was established in 1925. However, settler farmers have moved to occupy other areas of the reserve. Despite the intermittent destruction of such illegal settlements by the Ogun State Government, the problem has continued unabated. Population growth among the communities around the forest imposes a lot of pressure on the forest for subsistence farming (Salami, 2006).

The decrease in the areas covered with natural forests, monoculture plantations and roads, was expected. The reserve so far has lost about $70 \%$ of its original natural forest cover. A close observation at the 1987 and 2011 land use maps of the reserve reveals a drift in the natural forest cover. A larger portion of the natural forest was found at the northeastern part of the reserve as at 1987. However, the trend changed in 2011, with more of the remaining 
natural forest now seen at the northwestern part of the reserve. The natural forest cover in the northeastern part of the reserve was found to have been drastically reduced by plantation establishment (especially cocoa plantations, settlements, and farmlands). Ojo (2004) had earlier expressed concern about the high rate of de-reservation/deforestation in the northeastern part of the reserve, when he observed that only nine out of the sixteen one-hectare permanent sample plots established in 1985 at Abeku for high forest monitoring, were remaining as at the last enumeration in the year 2000. However, the gain in natural forest cover in the northwestern part of the reserve is most likely attributable to the conservation efforts of the Nigerian Elephant Project Group and the UNESCO Man and the Biosphere Programme. Recent studies (e.g. NCF, 2008; Ogunsesan et al, 2011) equally reported that most of the natural forest within Omo is now mainly confined to the northwestern part. This is also the area where the Nigerian Conservation Foundation and the Paignton Zoo have continued to maintain the Erin Camp as a base for visits by students and others. The observed drift in the abundance of the natural forest cover lends credence to the fact that forests are biologically renewable, and that the natural forest cover could be restored in degraded areas through an appreciable level of conservation.

The monoculture plantations decreased from about $26 \%$ of the total area of the reserve to about $11 \%$ within the period under consideration. This is largely due to unsustainable exploitation. The precursor of the Ogun State Forestry Plantation Project started in 1966 as Gmelina Pulpwood Plantation Project, with the aim of raising Gmelina arborea plantations for pulpwood that will feed Iwopin Pulp and Paper Mill. The then Western Region Government on its own, funded the project up to 1972 when a total of 2,000 hectares of Gmelina arborea plantation was established in Area J6 of the reserve (Karimu, 1999). Between 1973 and 1979, The Federal Government of Nigeria sustained the Project with grants for additional 6,000 hectares of Gmelina plantation. Ogun State through the Federal Government of Nigeria also took a loan from the World Bank, and utilized it to raise a further 10,000 hectares of Gmelina from 1980 - 1987. At the approach of the termination of the World Bank loan in 1987, African Development Bank (ADB) provided another loan which brought the total area covered with Gmelina plantation to 23,000 hectares as at 1995/1996 (Karimu, 1999). However, most of these plantations have been clear-felled without re-establishment and are now covered by secondary forests. Apart from Cocao plantations, those of other species are now found mainly around the central part of the reserve (Area J4).

The reduction in the area covered with roads may not be unconnected with the reduction in the plantation area, since the access roads leading to areas previously covered with plantations are no longer in use, and may have been covered with pioneer re-growths. One would also have expected an increase in roads following the rapid expansion of settlements. However, this was not the case as the ground-truthing exercise revealed that access to most of those settlements are mainly through tracts ( and not well constructed roads), probably as a result of their illegal nature.

The disturbed forests now cover a larger portion of the reserve (36\%) than any other land use type. The area covered by the disturbed forest is most likely going to increase in future due to 
the high rate of natural forest conversion in the reserve.

The land use analysis further revealed that the total area of the reserve is 148, 687 hectares, which suggests that the reserve may be about $14 \%$ larger in area than the 130, 500 hectares quoted by some workers (e.g. Ola-Adams, 1999; Ojo, 2004). The results obtained in this study with respect to the percentage areas covered by the respective land use types are completely at variance with figures quoted by Karimu (1999). Previous reports on the pattern of land use/land cover changes in the reserve have been based on casual observations and impressions and not detailed empirical/scientific methodologies. Salami (2006) through the application of remote sensing technologies made a similar observation when he discovered discrepancies in the actual rate of deforestation in Nigeria, and the figures quoted by FAO and the Nigerian Federal Department of Forestry; and underscored the need for relevant authorities to quantify the degradation of the Nigerian forest based on scientific methodologies rather than using surrogate data. Contemporary application of geoinfomatics technologies in vegetation and land use inventory, monitoring and mapping, has been recognized as the most effective means of natural resources data acquisition, analyses and information provision for management control and policy formulation (Ikhuoria and Ero, 1996).

The findings of this study were almost in agreement with that of NCF (2008) especially with respect to the extent and location of the remaining natural forest cover in the reserve. For instance, the study confirms that the remaining natural forest in the reserve is now mainly found at the northwestern part, with the SNR at the edge (close to Omo River), as reported by NCF (2008). However, the percentage area of the reserve covered with natural forest was found to be $3.25 \%$ higher than the figure $(28.8 \%$ ) quoted by NCF. There are two possible reasons for this slight difference - changes that have occurred between 2007 (when NCF conducted their study) and 2011, and the level of accuracy of the satellite imageries used. The mapping of the natural forest cover in the reserve by NCF was done using Aster imagery while this study employed Landsat $\mathrm{ETM}^{+}$imagery. Salami (2006) reported the highest overall accuracy for Landsat $\mathrm{ETM}^{+}$.

\section{Conclusion}

The study has shown a remarkable land use change in the reserve between 1987 and 2011. The farmlands, disturbed forests, settlements, and rivers have increased in area while the areas covered with natural forests, plantations, and roads have decreased. There are also very strong indications that the disturbed forest, which is now the most extensive land cover type in the reserve, will increase in area in the near future. It is expected that the information provided in this study will aid decisions that will enhance sustainable management of the reserve.

\section{Acknowledgements}

The authors are grateful to Mr. O.S. Adegbola - Assistant Director, Nursery and Plantation Establishment, Ogun State Plantation Project, Area J4, for providing relevant information on the study area, and for accommodating the researchers during the field trips. The Forest 
Attendant, SNR $1-$ Mr. A. O. Akanbi, is also deeply appreciated, for conducting us round the SNR 1 during the field trips. Mr. Jay Samak of the Tropical Rainforest Information Centre, Department of Forestry, Michigan State University, USA, is deeply appreciated for his technical support/assistance during the acquisition of satellite imageries used for the study. Mr. O. S. Eludoyin of the Department of Geography and Environmental Management, University of Port Harcourt, is also appreciated for the image analysis.

\section{References}

Carlson, T. N., \& Azofeifa, S. G. A. (1999). Satellite remote sensing of land use changes in and around San Jose', Costa Rica. Remote Sensing of Environment, 70, 247-256.

Chazdon, R. L. (2003). Tropical Forest Recovery: Legacies of Human Impact and Natural Disturbances. Prospect. Plant Ecol., 6, 51-71. http://dx.doi.org/10.1078/1433-8319-00042

Chijioke. E. O. (1980). The Impact on Soils of Fast growing Forest Species in Lowland Humid Tropics. FAO Forestry Paper No. 21. Rome, 111pp.

Evans, G. C. (1939). Ecological studies on the rainforest of Southern Nigeria II. The Atmospheric Conditions. J. Ecology, 27, 437-483.

FAO (2010). Global Forest Resources Assessment 2010. FAO Forestry Paper No. 163. FAO, Rome. 373pp.

Guerschman, J. P., Paruelo, J. M., Bela, C. D., Giallorenzi, M. C., \& Pacin, F. (2003). Land cover classification in the Argentine Pampas using multi-temporal Landsat TM data. International Journal of Remote Sensing, 24, 3381-3402.

Hall, J. B. (1977). Forest-Types in Nigeria: An analysis of pre-exploitation forest enumeration data. J. Ecol. 65, 187 - 199.

Howard, J. A. (1991). Remote Sensing of Forest Resources: Theory and Application, London: Chapman and Hall Publisher.

Ikhuoria, I. A., Ero, I. I., \& Ikhuoria, A. E. (2006). Satellite detection and GIS analysis of lowland rainforest reserve reduction in Edo State, Nigeria. In Salami, A. T. (Ed.), Imperatives of Space Technology for Sustainable Forest Management. Proceedings of an International Stakeholders' Workshop Sponsored by National Space Research and Development Agency (NARSDA), Abuja.

Isichei, A. O. (1995). Omo biosphere reserve: current status, utilisation of biological resources and sustainable management. South-South Co-operation on Environmentally Sound Socio-Economic Development in the Humid Tropics, Working Paper 11, UNESCO, Paris, 48pp.

Karimu, S. A. (1999). The role of surrounding communities on the management of Omo Forest Reserve. Consultant Report for FORMECU, June 1999, 47 pp.

Nigerian Conservation Foundation (NCF). (2008). A Survey of Rain Forests in Ogun, Ondo and Osun States in Southwestern Nigeria to Assess Options for Their Sustainable 
Conservation, NCF, Nigeria, 48pp.

Nuga, B. O., \& Akinbola, G. E. (2011). Land use/land cover change detection in Ikwuano area, Abia State, Nigeria using Landsat data, Nigerian Journal of Soil Science, 21(2), 61-68.

Ogunsesan, D., Oyedepo, J., Oates, J., Adeofun, C.O., Ikemeh, R. \& Bergl, R. (2011). GIS-Supported survey of lowland rain forests in South-western Nigeria. Proceedings of the Environmental Management Conference, Federal University of Agriculture, Abeokuta, Nigeria, 2011. Retrieved from http://www.unaab.edu.ng

Ojo, L. O. (2004). The fate of a tropical rainforest in Nigeria: Abeku sector of Omo Forest Reserve, Global Nest, 6(2), 116 - 130.

Ola-Adams, B. A. (1999). Biodiversity Inventory of Omo Biosphere Reserve, Nigeria. Country Report on Biosphere Reserves for Biodiversity Conservation and Sustainable Development in Anglophone Africa (BRAAF) Project. 351 pp.

Rajiv, R., \& Upandhyay, V. P. (1999). Ecological problems due to shifting cultivation. Retrieved September 11, 2011, from www.ias.in/currsci/nov25/article12.htm

Rogana, J., \& Chen, D. (2004). Remote sensing technology for mapping and monitoring land-cover and land-use change. Progress in Planning, 61, 301-325. http://dx.doi.org/10.1016/S0305-9006(03)00066- 7

Runge, J. (2006). Imperatives of remote sensing-based forest assessment: The example of Ngotto Forest, Central African Republic. pp. 62-71. In Salami, A. T. (Ed.), Imperatives of Space Technology for Sustainable Forest Management. Proceedings of an International Stakeholders' Workshop Sponsored by National Space Research and Development Agency (NARSDA), Abuja.

Salami, A. T. (1999). Vegetation dynamics on the fringes of lowland tropical rainforest of Southwestern Nigeria - An assessment of environmental change with Air Photos and Landsat TM, International Journal of Remote Sensing, 20(6), 1169 -1182.

Salami, A. T. (2006). Monitoring Nigerian Forest with NigeriaSat-1 and other satellites pp 28 - 61. In Salami, A. T. (Ed.), Imperatives of Space Technology for Sustainable Forest Management. Proceedings of an International Stakeholders' Workshop Sponsored by National Space Research and Development Agency (NARSDA), Abuja.

Salami, A. T., Ekanade, O., \& Oyinloye, R. O. (1999). Detection of forest reserve incursion in Southwestern Nigeria with a combination of multi-date aerial photographs and high resolution satellite imagery, International Journal of Remote Sensing, 20(8), 1487-1497.

Zsuzsanna, D., Bartholy, J., Pongracz, R., \& Barcza, Z. (2005). Analysis of land-use/land-cover change in the Carpathian region based on remote sensing techniques. Physics and Chemistry of Earth, 30, 109-115. 